Renata Sulewska

Instytut Historii Sztuki

Uniwersytet Warszawski

http://dx.doi.org/10.18778/2084-851X.05.06

\title{
Przedstawienie Litanii Loretańskiej w ołtarzu Najświętszej Marii Panny z klasztoru Reformatów w Poznaniu
}

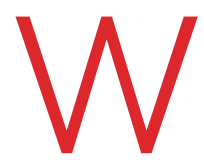

1752 roku gwardian klasztoru w Poznaniu, ojciec Jakub Suwaliński, po przeprowadzeniu remontu kościoła, zatrudnił Józefa Hybnera ${ }^{1}$ do wykonania nastawy ołtarza głównego. Rozpoczął tym samym realizację uchwały kapituły prowincjalnej, obradującej w 1741 roku w Łąkach Bratiańskich, nakazującej wymianę ołtarzy w świątyniach reformatów prowincji wielkopolskiej ${ }^{2}$. Kolejne działania zmierzające do ukształtowania nowego wystroju poznańskiej świątyni zostały podjęte przez następców Suwalińskiego. Dzięki staraniom gwardiana o. Alojzego Płacheckiego kontynuowano prace nad ołtarzem głównym, wzniesiono sześć ołtarzy bocznych, dwie szafy obok ołtarza 
głównego, wykonano też nowe wyposażenie zakrystii ${ }^{3}$. Kolejne elementy wyposażenia i wystroju kościoła zostały zrealizowane przez ojca Mansweta Sikorskiego, który „wzbogacił ozdobami i uzupełnił [...] budowę ołtarza głównego”. Przyczynił się on do powstania: ambony, czterech konfesjonałów, ławek, skrzyni na drobne sprzęty, „kratek na świeckim chórze” oraz gipsowych popiersi apostołów, figury Chrystusa umieszczonej naprzeciwko ambony, a także balasków przed ołtarzem głównym ${ }^{5}$. Realizowane przez sześć lat prace zostały ukończone w maju 1758 roku$^{6}$.

Do wykonania ołtarzy bocznych zatrudniono Józefa Eglauera, snycerza z Rawicza $^{7}$, sprawdzonego już przy realizacji wyposażenia kościoła Reformatów w Choczu (1750-1751). Duży zespół jego współpracowników (wśród których był jego syn Jerzy), pozwalający na realizację kilku zleceń prawie równocześnie ${ }^{8}$, uzupełniało dwóch braci zakonnych: Stanisław Kampey (Gampey) - malarz oraz Jan Guze stolarz i snycerz ${ }^{9}$. Ten ostatni samodzielnie wykonał do poznańskiej świątyni ławki ustawione w nawie i zamontowane tam kratki, być może ukończył ołtarz główny, a także pokrył pokostem kilka wykonanych wcześniej prac ${ }^{10}$, przyczyniając się do sporych oszczędności.

Za gwardiana Wojciecha Gołeckiego w klasztorze pojawił się jeszcze jeden ołtarz. Stanął w 1763 roku „w dolnych krużgankach” przy wejściu prowadzącym do refektarza ${ }^{11}$. Za jego wykonanie zapłacono rzeźbiarzowi 100 tymfów polskich, dodatkowo wynagradzając go czterema miarami jęczmienia, dwiema pszenicy i beczką piwa ${ }^{12}$. Czternastego sierpnia, w wigilię Wniebowzięcia NMP, wykonana $\mathrm{z}$ sosnowego drewna ${ }^{13}$ (a więc innego niż ołtarze w kościele ${ }^{14}$ ) nastawa została pokryta werniksem ${ }^{15}$. W święto Wniebowzięcia NMP przy nowym ołtarzu pierwszą mszę świętą odprawił ojciec gwardian, a w kolejnych dniach pozostali zakonnicy ${ }^{16}$.

Mimo wielu szczegółowych informacji dotyczących tego ołtarza, jakie znajdujemy w Kronice Reformatów poznańskich ${ }^{17}$, nie zostało tam niestety odnotowane

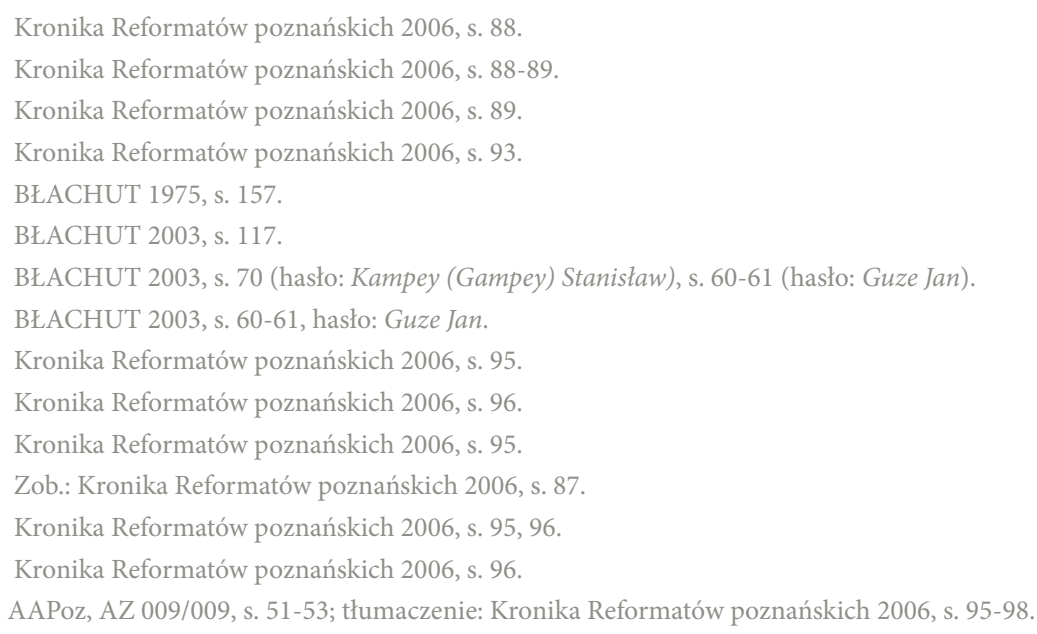


nazwisko jego wykonawcy. Nie mógł nim być brat Jan Guze, który zmarł w 1760 roku. Czynny był co prawda jeszcze Józef Eglauer, zmarły w roku 1766 w Lutomier$\mathrm{sku}^{18}$. W drugiej połowie lat 50. i na początku 60. XVIII wieku zatrudniono go do wykonania wystrojów kolejnych kościołów reformatów ${ }^{19}$, ale kronikarz nie sugeruje, że nastawa ta powstała $w$ jego warsztacie ${ }^{20}$.

Burzliwe dzieje poznańskiego kościoła i klasztoru ${ }^{21}$ spowodowały, że nie wszystkie elementy jego wyposażenia i wystroju zachowały się. Ołtarz przy refektarzu stał do 1803 roku, kiedy to został przeniesiony w pobliże zakrystii ${ }^{22}$. Nie przetrwał także i tam i niestety nie wiemy, co się z nim stało.

Pozostało po nim rzadko spotykane źródło - szczegółowa relacja zamieszczona w Kronice (Aneks) ${ }^{23}$ - wpisana pod rokiem 1760 - Pro Memoria et Conservatione praefati Altaris ${ }^{24}$. Informacje dotyczące programu i elementów kompozycji ołtarza zostały spisane w dość szczególnej formie. Kronikarz ściśle podporządkował je układowi Litanii Loretańskiej.

Ołtarz poświęcony był Najświętszej Marii Pannie i przedstawiał „poszczególne tajemnice Litanii Loretańskiej, poczynając od Kyrie elejson, aż do Baranku Boży włącznie”25. Chociaż we wprowadzeniu do „opisu” ołtarza zaznaczono, że „wyjaśnione zostają poszczególne zawarte w nim tajemnice Litanii" ${ }^{26}$, to nie zawiera on objaśnienia ich znaczeń, lecz tylko zestawienie wezwań z odnoszącymi się do nich symbolami i niekiedy miejscem ich usytuowania w nastawie. Poza jednym przypadkiem (dotyczy to hebla i dzwonu) autor relacji nie wskazał źródła symboli i tylko dwa razy podał ich znaczenie (Pannę łaskawą ukazywało berło umieszczone na ołtarzu

\footnotetext{
18 BŁACHUT 2003, s. 115, przypis 27.

19 BŁACHUT 2003, s. 121.

20 W Kronice wzmiankowani są dwaj stolarze luteranie pracujący circa Altaria w 1755 roku,

a więc okresie intensywnych prac nad wyposażeniem wnętrza kościoła. Nie jest jasne czy można ich pracę wiązać również z interesującą nas nastawą. Jeśli tak, to początek jej realizacji należałoby przesunąć aż do 1755 roku. Wydaje się to jednak bardzo mało prawdopodobne, tym bardziej, że na umieszczone w niej przedstawienia miały wpływ wydarzenia mające miejsce w kościele w roku 1761. Dodatkowo ustawienie omawianej nastawy przypisane jest staraniom gwardiana Wojciecha Gołeckiego wymienianego w Kronice od 1760 roku. Prace nad nią rozpoczęto zapewne po 1761 roku. Zob.: Kronika Reformatów poznańskich 2006, s. 94-96.

21 KURZAWA 1997, s. 133-136.

22 Kronika Reformatów poznańskich 2006, s. 95. W opublikowanym tłumaczeniu błędnie podano rok 1853 jako datę przeniesienia ołtarza, podczas gdy w oryginale jest 1803 (Zob.: AAPoz, AZ 009/009, s. 51).

23 AAPoz, AZ 009/009, s. 52-53; Kronika Reformatów poznańskich 2006, s. 96-98.

24 AAPoz, AZ 009/009, s. 52; „Ku pamięci i dla ocalenia [jego] [przesłania]” - Kronika Reformatów poznańskich 2006, s. 96. Należy odnotować, że mimo, iż w Kronice wspomniane są inne ołtarze, żaden nie został opisany tak szczegółowo. 
„jako znak łagodności”27, a siedem pieczęci księgi, nad którą umieszczony był Baranek Boży, przedstawiało, według autora Kroniki, siedem grzechów głównych) ${ }^{28}$.

Zamieszczony w opisie formularz Litaniii ${ }^{29}$, zatwierdzonej oficjalnie w 1587 roku bullą papieża Sykstusa V, odpowiada funkcjonującemu między rokiem 1631 a 1815.

27 Ibidem, s. 97.
28 Ibidem, s. 98.
$29 \quad$ Przytaczane w artykule wezwania Litanii Loretańskiej zostały zaczerpnięte z tłumaczenia Kroniki.
Zob.: Kronika Reformatów poznańskich 2006, s. 96-98.

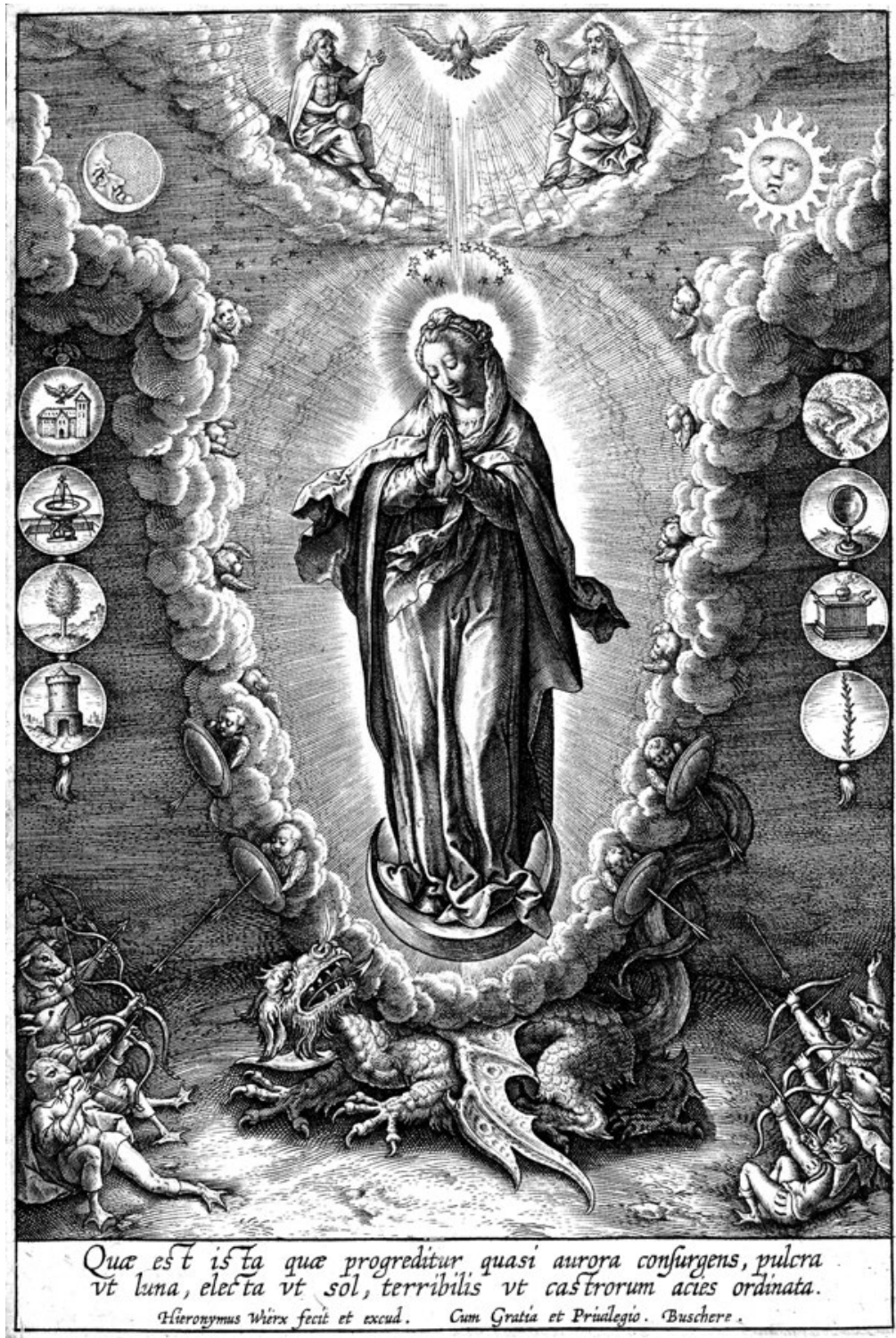

Maria z symbolami

z Litanii Loretańskiej,

Hieronymous (Jérôme) Wierix,

przed 1615,

Fot. @ Victoria EAlbert Museum, Londyn 
Pierwsza data (2 sierpnia) związana jest z dekretem Świętej Kongregacji Obrzędów, zakazującym, bez zgody Stolicy Apostolskiej, dokonywania zmian w oficjalnym tekście Litanii, który w 1601 roku zatwierdził papież Klemens VIII. Druga data wiąże się z decyzją papieża Piusa VII (15 września) o dołączeniu wezwania - Auxilium christianorum ora pro nobis ${ }^{30}$. Zgodnie z polską tradycją spisany w Kronice formularz Litanii, na podstawie którego opracowany był program nastawy, został wzbogacony o wezwanie - Regina Regni Poloniae, dodane w 1656 roku $^{31}$ (chociaż urzędowo zatwierdzone dopiero w roku 1908 przez papieża Piusa $\mathrm{X}^{32}$ ).

Użyte w ołtarzu symbole można wywieść z kilku źródeł. Część z nich to obrazujące tytuły Marii ${ }^{33}$ popularne symbole biblijne, spopularyzowane przez typologiczne dzieła średniowieczne i przejęte do dzieł nowożytnych, między innymi Godzinek o Niepokalanym Poczęciu NMP, Litanii Loretańskiej i przedstawień Niepokalanego Poczęcia NMP ${ }^{34}$. Część została wypracowana na podstawie innych źródeł, między innymi pism starożytnych filozofów, ojców Kościoła, mitologii, obserwacji natury czy ikonografii świeckiej ${ }^{35}$. Podobnie jak poprzednie, były rozpowszechniane przez poświęcone Marii i Litanii prace symbolograficzne ${ }^{36}$ oraz druki emblematyczne ${ }^{37}$, których popularność stopniowo narastała od ukazania się pierwszej publikacji tego rodzaju - pracy Petrusa Sterglerusa (Petera Stoerglera) Asma Poeticum litaniarum lauretanarum, wydanej w 1636 roku w Linzu ${ }^{38}$. Na emblematyczne źródło użytych w ołtarzu symboli mogą wskazywać: oko z promieniem, odnoszące się do wezwania

\footnotetext{
30 GRZYBEK 1951, s. 99-100.

31 Po raz pierwszy wezwanie to zostało dodane do odmawianej w Polsce Litanii Loretańskiej przez nuncjusza Pietra Vidoniego podczas nabożeństwa, które odbyło się w obecności króla Jana Kazimierza w kościele Jezuitów we Lwowie, po złożeniu przez władcę ślubów w tamtejszej katedrze. SKRUDLIK 1930, s. 138, 147; GLEMMA 1956, s. 196; KNAPIŃSKI 2005, s. 53. GRZYBEK 1951, s. 100; SKRUDLIK 1930, s. 140. WOJTCZAK 2010

KLAWEK 1956; FOURNÉE 1970; BIERNACKA 1987, s. 44; KNAPIŃSKI 1999, s. 193, 196, 199; BARKER 2010, s. 110-131; WOJTCZAK 2017; ŁUKARSKA 2010, s. 172-175.

35 KNAPIŃSKI 1999, s. 205-207; MONTERROSO MONTERO 2003, s. 367-378; ŁUKARSKA 2010, S. $175-182$.

36 Jak np. MARRACCI 1683.

37 KNAPIŃSKI 2005, s. 34-36; LÓPEZ CALDERÓN 2010-2012; LÓPEZ CALDERÓN 2012-2013; LÓPEZ CALDERÓN 2016. Zob. też: KEMP 1989, s. 331-334.

38 Kolejne druki powstałe pod wpływem Asma Poeticum (STOERGLER 1636) ukazały się wraz z początkiem XVIII wieku. Opublikowana w 1700 roku w Augsburgu - Elogia Mariana zawiera ryciny z wezwaniami, obrazami, anagramami i czterowierszowymi subskrypcjami Augusta Casimira Redela oraz komentarze i modlitwy opracowane przez Isaaca von Ochsenfurtha (Isaac Oxoviensis; OXOVIENSI 1700). Jej niemieckie tłumaczenie ukazało się trzy lata później w Würzburgu. W 1732 roku w Augsburgu ukazała się nowa wersja Elogia Mariana z rycinami Martina Engelbrechta, opartymi na wcześniejszych ilustracjach, ale przeprojektowanych przez Thomasa Schefflera (REDEL 1732; AMARAL 2011, s. 11). O zależności między tymi publikacjami zob. też: LÓPEZ CALDERÓN 2013, s. 51-63.
} 
„Matko łaski Bożej” ${ }^{39}$, pierścień na wieńcu z kwiatów - „Panno wierna” czy umieszczone na wieży Dawidowej „słońce, [...] które dotyka błota i nie ulega zabrudzeniu” "40estawione z wezwaniem - „Matko dziewicza”. „Narracyjność” tego ostatniego symbolu przypomina opis $i k o n u$ emblemu. Jako pewnego rodzaju analogię dla niego można wskazać symbolum z mottem Radio solari, lutum non nocet do Conceptus $X C V$ w opublikowanej w 1720 roku pracy Josepha Zollera Conceptus chronographi$\mathrm{cus}^{41}$. Pomocne przy wyborze symboli odpowiadających wezwaniom Litanii Loretańskiej mogły być ilustrowane wydania tej modlitwy. Szczególną popularność zyskała opublikowana po raz pierwszy w Augsburgu w 1749 roku Litania Loretańska z tekstem Franza Xavera Dorna, ilustrowana rycinami opracowanymi przez Josepha Sebastiana i Johanna Baptistę Klauberów, pod „teologicznym natchnieniem” jezuity Urlicha Probsta ${ }^{42}$. Praca, której struktura wyraźnie odwołuje się do publikacji emblematycznych, zawierająca komentarze, medytacje i modlitwy, doczekała się licznych powtórzeń, tłumaczeń i wydań opatrzonych innymi tekstami ${ }^{43}$. Oryginalne ryciny Klauberów były powielane i przekształcane przez innych artystów, dodawano też ryciny, odpowiadające nowym wezwaniom Litanii, wykorzystywano je w końcu jako wzory dla dzieł malarskich i rzeźbiarskich ${ }^{44}$. Już na pierwszej rycinie - umieszczonej przed stroną tytułową - odnajdujemy wiele z symboli użytych w poznańskim ołtarzu. Powtarzają się one także w rycinach Klauberów przyporządkowanych poszczególnym wezwaniom, wplecione w sceny o symboliczno-narracyjnym charakterze.

Jak można sądzić, zawarty w poznańskim ołtarzu zestaw wezwań i symboli nie jest oparty na jednym źródle. Nawet gdyby można było takie wskazać, to zostało ono w istotny sposób zmodyfikowane przez wprowadzenie symboli o „lokalnym” pochodzeniu. Za takie należy bowiem uznać wyobrażenie orła polskiego, trzymającego w dziobie koronę, obrazujące wezwanie Regina Regni Poloniae ${ }^{45}$. Takimi są również przedstawienia hebla oraz dzwonu odpowiadające wezwaniu „Matko przedziwna”. Odwołują się one do wydarzeń, jakie miały miejsce w poznańskim klasztorze, których bez wskazania właściwego odniesienia nie można by było prawidłowo odczytać. Dobrze zdawał sobie z tego sprawę kronikarz skoro zapisał:

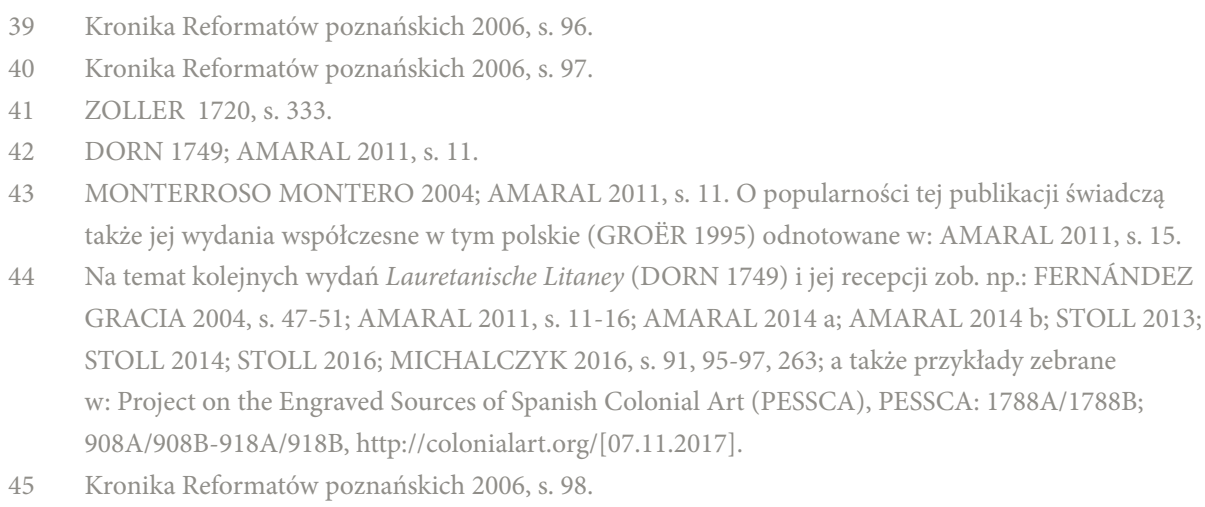


F.X. Dorn,

Litaniae Lauretanae

Ad Beatae Virginis,

Caelique Reginae Mariae...,

Augustae Vindelicorum 1771, rycina przed stroną tytułową

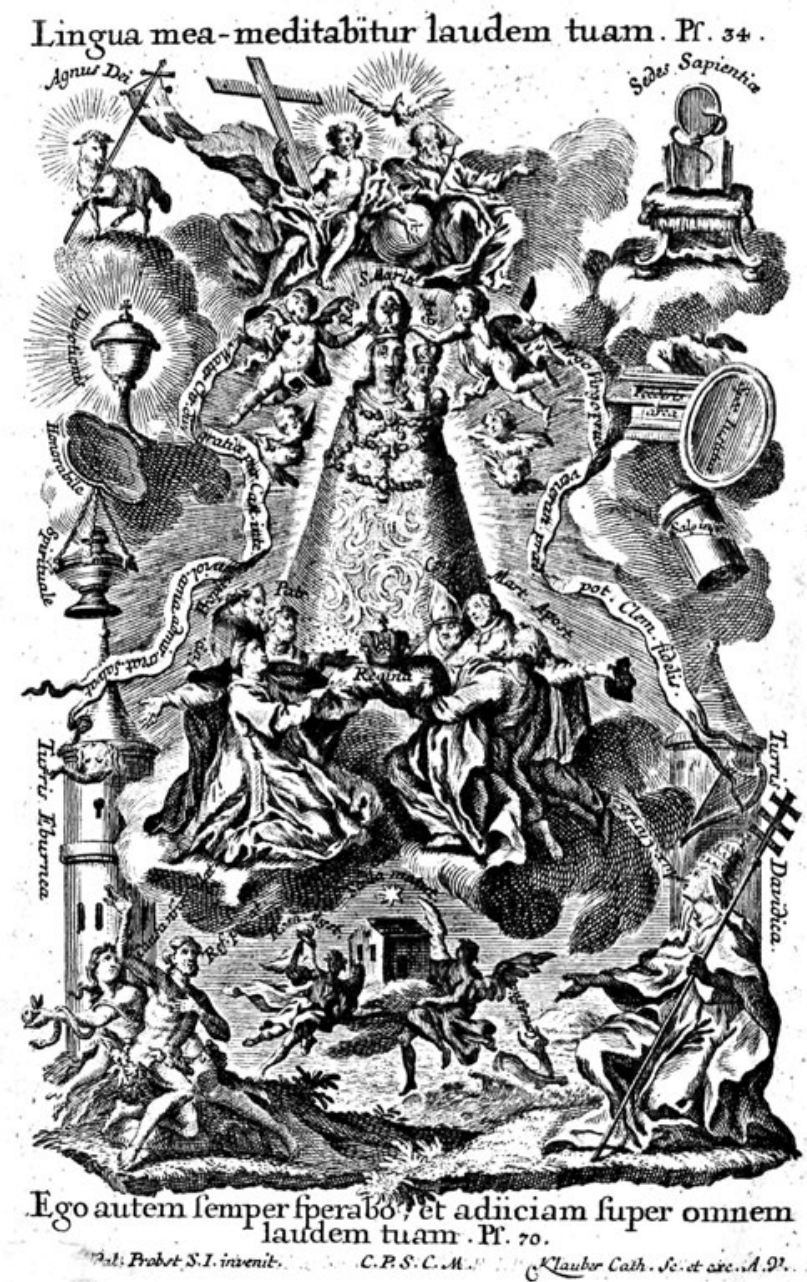

Aby zaś nie rodziło niejasności dodanie do wieży Dawidowej [...] narzędzie stolarskie, zwane pospolicie Hebel, trzeba wiedzieć, że za jego pomocą przestawiono Matkę Przedziwną, z powodu dwóch wydarzeń. Mianowicie dla pierwszego, które miało miejsce w roku 1755, kiedy pracujący przy ołtarzu dwaj stolarze, luteranie, ilekroć przechodzili obok obrazu umieszczonego w starym ołtarzyku bez okazania mu należnej czci, tyle razy cierpieli drgawki i utratę świadomości, mocą Bożą rzucani o ziemię i zmuszeni wbrew woli do oddania czci Bożej Rodzicielce $[\ldots]^{46}$. Dzwon zaś przypomina drugie zdarzenie, z roku 1761, za rządów tego samego przełożonego wielebnego o. Wojciecha Gołeckiego ${ }^{47}$. Nakazał on wówczas umieścić przy ścianie, pod dzwonem drzwi sąsiadujących $\mathrm{z}$ ołtarzem [...] nowo zakupioną blaszaną lampę, przez cześć dla obrazu. Nazajutrz po pierwszej nocy, kiedy światło zapłonęło przed wizerunkiem [NMP], 
nie wiem, jakim zrządzeniem losu, być może za sprawą sztuczki diabła zazdroszczącego czci Najświętszej [MP], dzwon urwawszy się ze swoich zawieszeń, z taką wielką siłą uderzył w lampę, że stojący w pobliżu sądzili, iż ją potrzaskał. W każdym razie, dzięki mocy Matki Przedziwnej, zarówno przewrócona lampa, jak i dzwon zrzucony na ziemię nie uległy rozbiciu. Dlatego wspomniane wydarzenie przedstawia dzwonek zawieszony przy ołtarzu ${ }^{48}$.

Wydaje się, że pomimo dawnej tradycji łączenia tytułów, jakimi obdarzano Marię, z określonymi symbolami oraz dużej popularności ich plastycznych wyobrażeń (również w ilustrowanych drukach zawierających tekst Litanii Loretańskiej lub

48 Kronika Reformatów poznańskich 2006, s. 96. Przytoczony fragment jest szczególnie dla nas interesujący, bowiem uzmysławia ograniczenia interpretacji przy braku tego rodzaju źródeł.

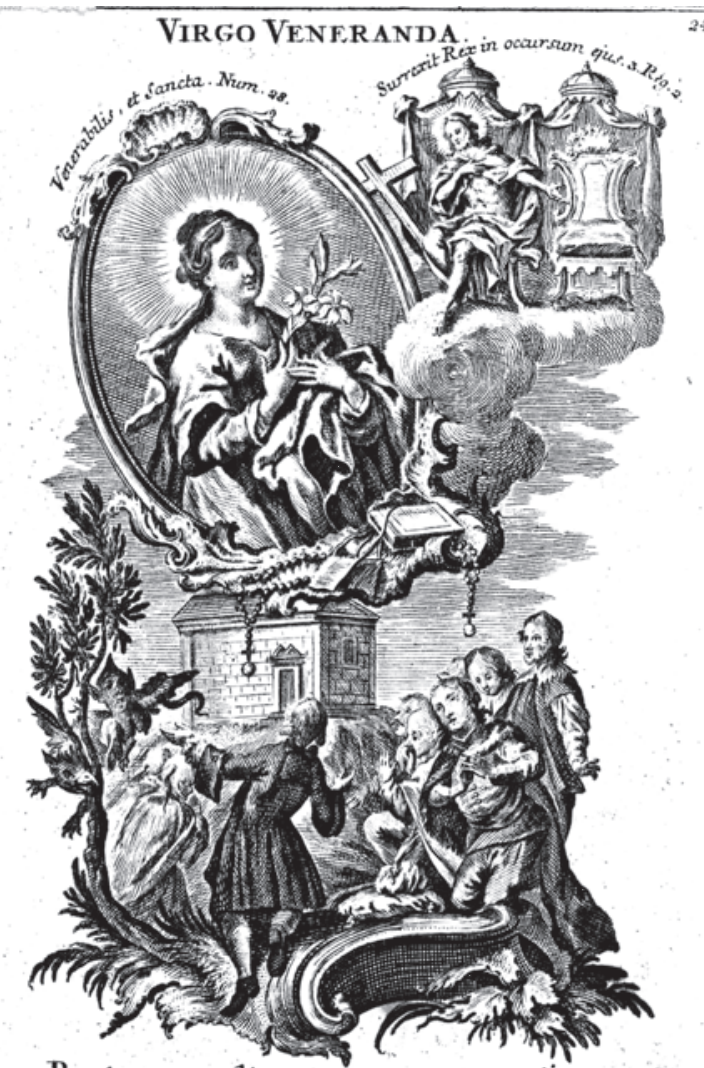

Beatam me dicent omnes generationes. c.P.S.C.M.

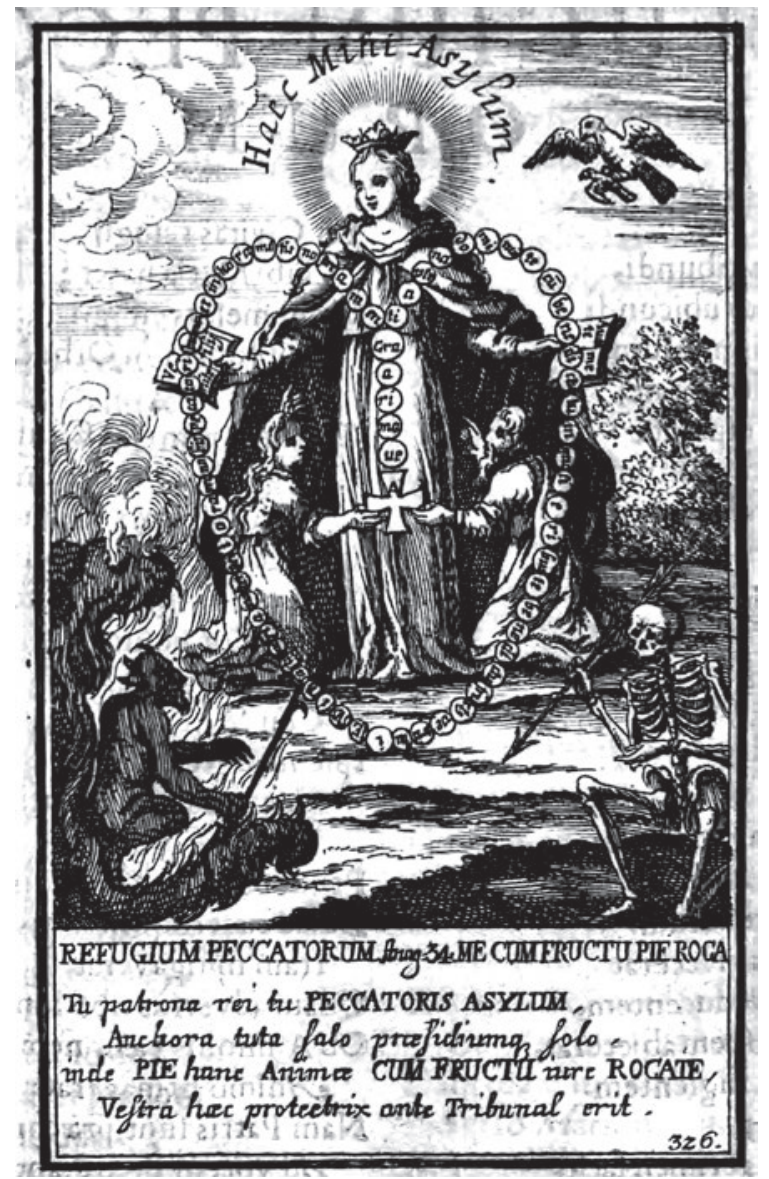

Isaac Oxoviensis, Elogia Mariana Ex Lytaniis LauretanisDeprompta..., Augustae 1700, rycina z wezwaniem Refugium peccatorum 
odwołania do niej), nie tylko te dwa wyjątkowe symbole były nieoczywiste, skoro autor zdecydował się na opisanie całego ołtarza (stąd płynie też wniosek, że przedstawienia nie były podpisane). Wśród umieszczonych w nastawie symboli, poza tymi jednoznacznymi skojarzeniowo, jak: róża - oznaczająca „Różę duchowną”, domek - oznaczający,„Dom złoty”, czy arka oznaczająca „Arkę Przymierza”, występują też takie, które zdają się mieć mniej utrwalony związek z poszczególnymi wezwaniami. Niektóre ukazane $\mathrm{w}$ ołtarzu symbole bywały bowiem zestawiane $\mathrm{z}$ innymi wezwaniami, niż wskazane w opisie. Jako przykład może posłużyć różaniec umieszczony w poznańskim retabulum na wieży z kości słoniowej, który według zapisu w Kronice przedstawiał „Pannę czcigodną” ${ }^{49}$. W takim zestawieniu użyli go też Klauberowie w rycinie odnoszącej się do tego wezwania zamieszczonej w Lauretanische Litaney ${ }^{50}$. Chociażby jednak w Asma poeticum i Elogia Mariana jest on elementem przedstawienia wezwania „Ucieczko grzeszników”51, które w poznańskim ołtarzu przedstawiał konfesjonał ${ }^{52}$. Z kolei na przykład w poświęconym Litanii Loretańskiej emblematycznym dziele Abrahama a Sancta Clara (pseud. Theophilo Mariophilo) Stella ex Jacob Orta Maria, opublikowanym w Wiedniu w 1680 roku, różaniec nie pojawia się w ogóle ${ }^{53}$. Nie wykluczone, że właśnie ta „nieoczywistość”, niektórych symboli, skłoniła kronikarza do zapisania przesłania ołtarza. Być może wykorzystał on wcześniejsze, znane w klasztorze (ustne?) wyjaśnienie zestawień symboli $\mathrm{z}$ wezwaniami Litanii.

Punktem odniesienia przy próbie rekonstrukcji poznańskiego retabulum mogą być nastawy, w których wykorzystano wiele przedstawień, symboli czy emblemów. Wśród realizacji tego rodzaju można wyodrębnić dwa główne typy. W pierwszym, do architektonicznej struktury dodane są rzeźbione symbole (przedstawienia) albo kartusze z ich wyobrażeniami, aplikowane do nastawy lub podtrzymywane przez umieszczone w niej figury. Drugi typ reprezentują retabula antyarchitektoniczne z przedstawieniami lub symbolami wplecionymi w ornamentalną ramę. Jako przykłady rozwiązań pierwszego typu mogą posłużyć trzy nastawy. W ołtarzu Matki Boskiej Różańcowej (ok. połowy XVII wieku) w kościele pw. św. Stanisława w Kobylinie $^{54}$ liczne namalowane w polach kartuszy sceny rozmieszczone są wokół wizerunku osadzonego pośrodku dolnej części nastawy. W ołtarzu w kaplicy Bożego Ciała (1753) w kościele śś. Janów w Toruniu ${ }^{55}$ część umieszczonych w kartuszach

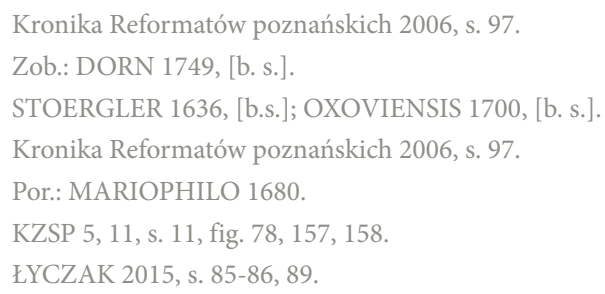




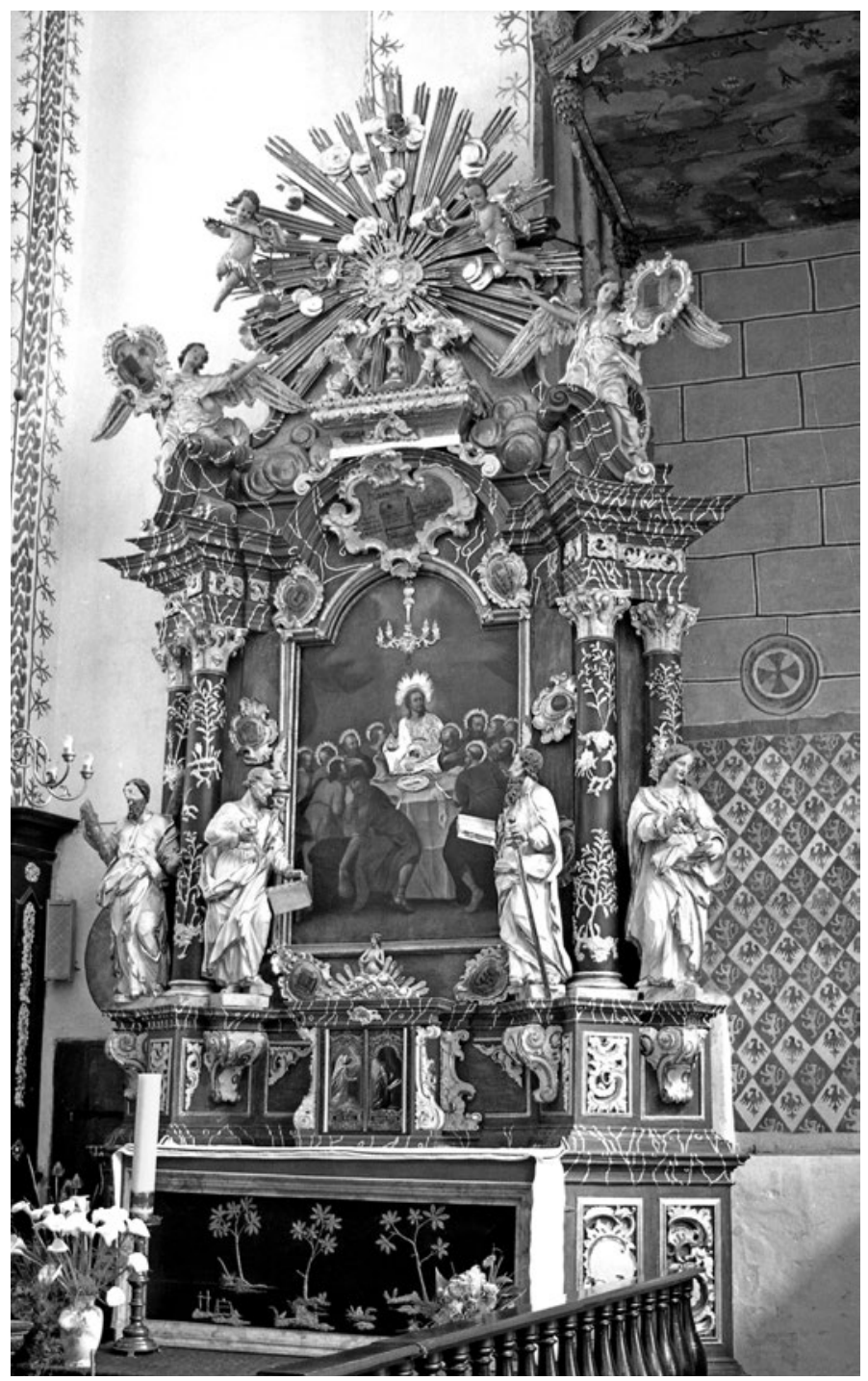

Toruń, kościół św. Jakuba,

ołtarz w kaplicy

Bożego Ciała, 1753,

fot. Mariusz Smoliński

emblematycznych przedstawień przymocowano wokół zajmującego centralne pole obrazu Ostatnia wieczerza, inne podtrzymują siedzące na wolutach anioły. Z kolei w wiązanych z Jerzym Judą Tadeuszem Dąbrowiczem, analogicznych pod względem struktury ołtarzach w kościele Trójcy Przenajświętszej w Dzierzgoniu ${ }^{56}$ - Narodzenia Pańskiego (w nawie północnej, 1739) i Matki Boskiej Różańcowej (w nawie południowej; - na dodanych po bokach, zwieńczonych rzeźbionymi „symbolami” obeliskach zawieszono kartusze z przedstawieniami i festony ${ }^{57}$. Drugi typ reprezentuja chociażby: ołtarz w kaplicy Matki Bożej Bolesnej w kościele parafialnym Misjonarzy

56 WARDZYŃSCY 2013, s. 876-878.

57 SZCZEPIŃSKA 2016, s. 175-177, il. 4. 
Dzierzgoń,

kościół Trójcy Przenajświętszej, ołtarz Matki Boskiej Różańcowej, około 1739, fot. Michał Wardzyński

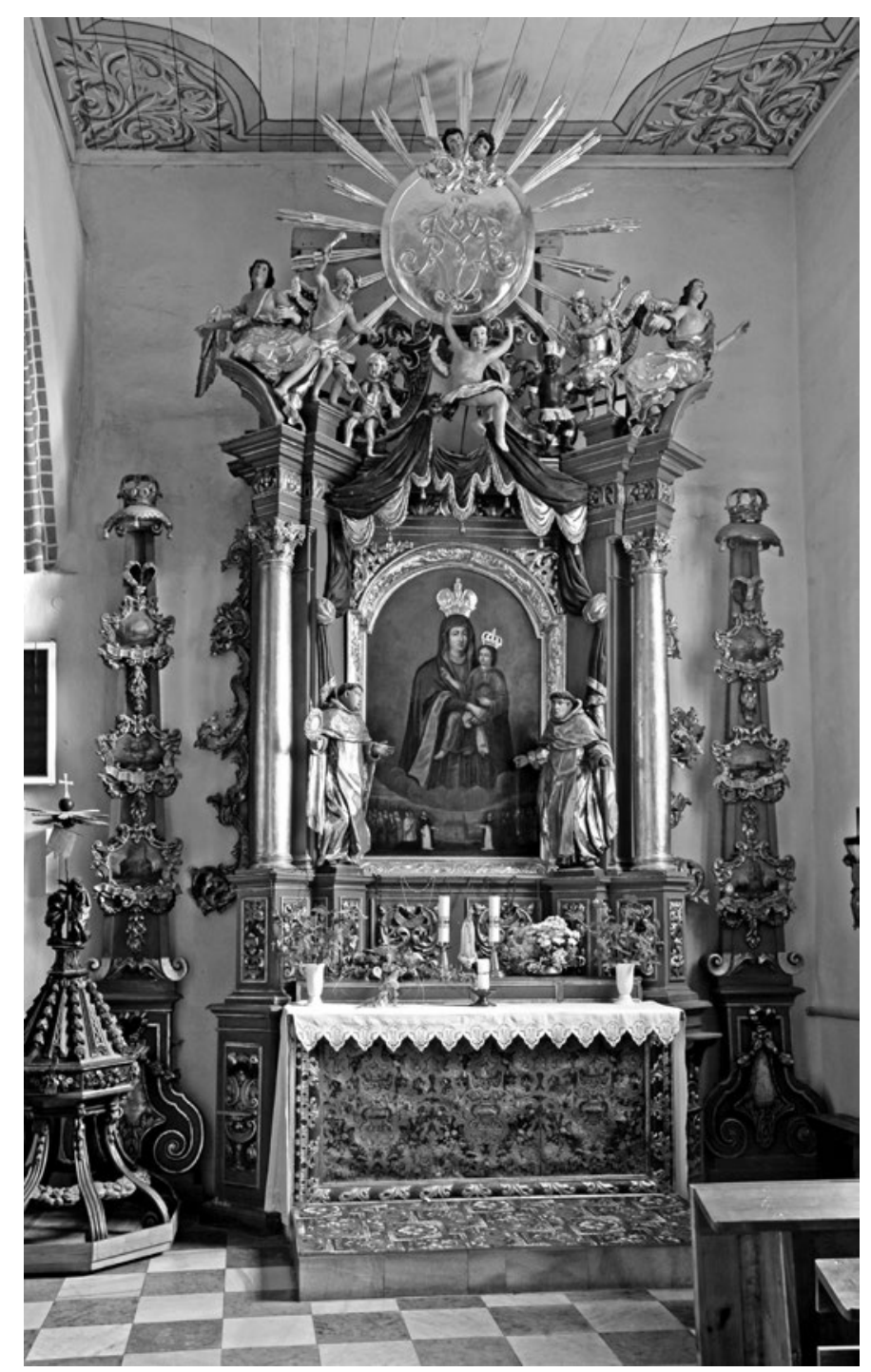

w Chełmnie (1699), wiązany z Johannesem Söffrensem ${ }^{58}$, czy ołtarz główny w kościele parafialnym w Ostromecku pod Toruniem ${ }^{59}$.

Z zawartego w Kronice opisu ołtarza NMP z klasztoru Reformatów w Poznaniu można wnioskować, że należał on do pierwszego spośród wyodrębnionych typów, a wszystkie jego elementy - struktura i uzupełniające ją przedstawienia - miały symboliczne znaczenie. Autor opisu odnotował bowiem, że „Bramę niebieską przedstawia środkowa część ołtarza otaczająca z obu stron wizerunek [NMP]”“60. Podążając

\footnotetext{
$58 \quad$ KZSP 11, 4, s. 16, fig. 142; WARDZYŃSKA 2014, s. 146, il. 10.

59 KZSP 11, 4, s. 110, fig. 143.

60 Kronika Reformatów poznańskich 2006, s. 97; AAPoz AZ009/009 - s. 53 (Januam Caeli designat Medium Altaris Iconem ambiens).
} 


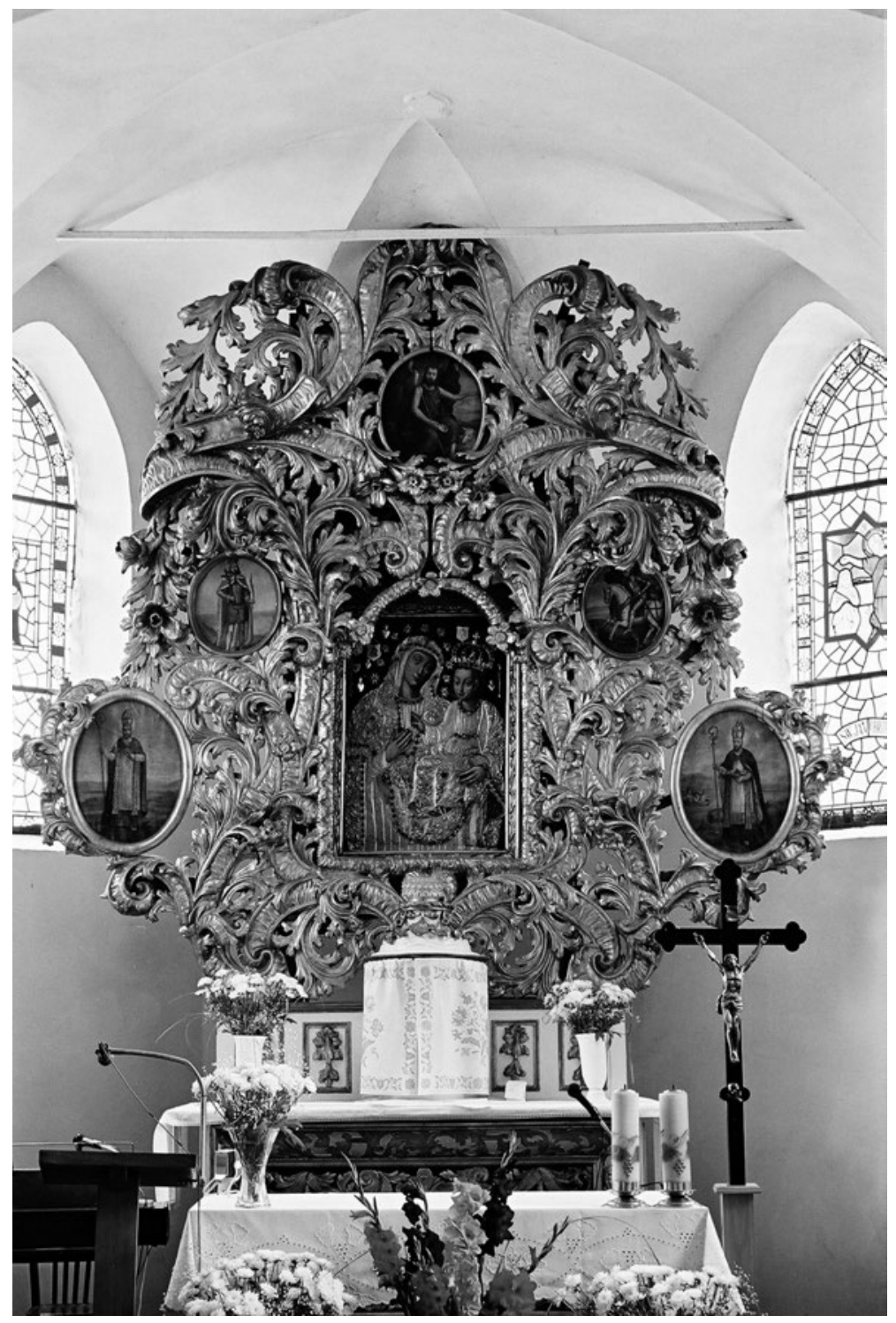

Ostromecko,

kościół parafialny, ołtarz główny, 1. ćw. XVIII w., fot. Michał Wardzyński

za tekstem możemy z dużym prawdopodobieństwem odtworzyć ogólną strukturę retabulum, natomiast ustalenie dokładnego rozmieszczenia wszystkich symboli nie jest możliwe. Autor, którego celem było przekazanie przesłania ołtarza, wymienił je w kolejności odpowiadającej wezwaniom Litanii Loretańskiej, nie zawsze odnotował miejsca ich usytuowania; niekiedy jego określenia są nieprecyzyjne, dlatego też w niektórych przypadkach trudno uchwycić wzajemne relacje pomiędzy poszczególnymi przedstawieniami. Tylko w przybliżeniu możemy określić jak ołtarz był wykonany. $Z$ opisów symboli możemy wnioskować, że przynajmniej część była rzeźbiona i niektóre złocone ${ }^{61}$. 


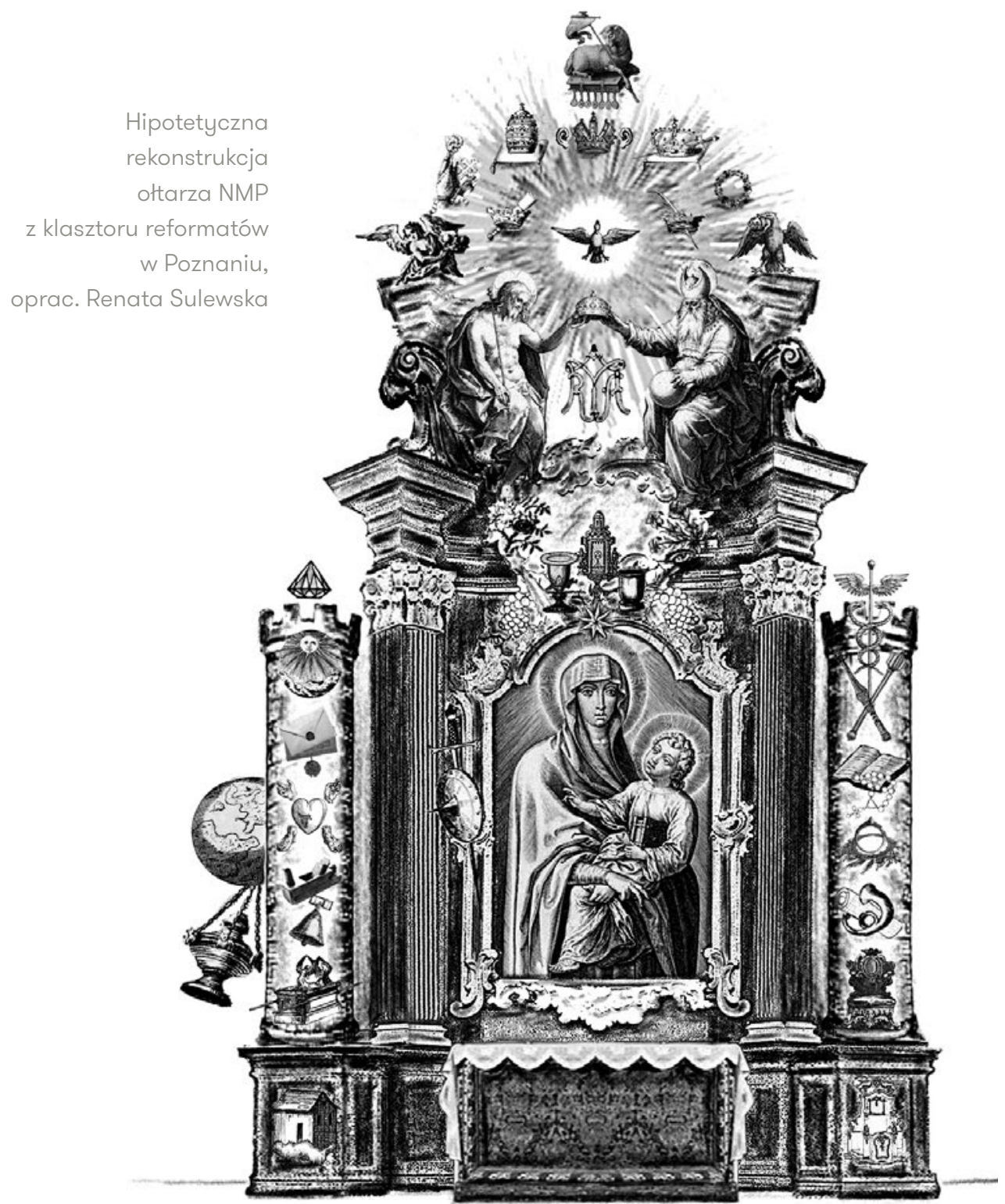

W środkowej części nastawy - przypominającej bramę (a więc może w formie aediculi) umieszczony był wizerunek Marii z Dzieciątkiem (malowany?), obrazujący wezwanie Litanii - „Matko Jezusa Chrystusa”. Otaczało go kilka symboli. Ponad nim znajdowały się te przedstawiające naczynia - kielich z pateną (Naczynie duchowne), puszka z Najświętszym Sakramentem (Naczynie poważne) i naczynie aptekarskie (Uzdrowienie chorych). Ponadto nad wizerunkiem umieszczona była gałązka winnej latorośli z winnym gronem (Pocieszycielka strapionych) i gwiazda (Gwiazda zaranna), a u jego boku tarcza z mieczem (Wspomożenie wiernych). Natomiast kadzielnica (Naczynie osobliwe nabożeństwa) zawieszona była po lewej stronie ołtarza. Na szczycie nastawy (zapewne więc już w partii zwieńczenia) znajdowało się wyraźnie widoczne przedstawienie Trójcy Świętej. Po bokach retabulum dodane były dwie wieże - Dawidowa po 
lewej i z kości słoniowej po prawej. Ponieważ na wieżach, z ich boków i pod nimi, umieszczony był szereg symboli, można wnioskować, że były to duże elementy, może wysokością dorównujące środkowej części nastawy. Na szczycie wieży Dawidowej wprawiony był kryształ oznaczający „Matkę najczystszą”. Dodatkowo znajdowały się na niej: słońce dotykające błota i nieulegające zabrudzeniu (Matka dziewicza), list z pieczęcią (Matka niepokalana i nienaruszona), hebel i dzwon (Matka przedziwna), wyrzeźbione serce (Matka najmilsza) i pięć ran Chrystusa (Matka Zbawiciela) oraz wysuwający się z boku świat (globus? kula ziemska? - Matka Stworzyciela). Podobnie zapełniona symbolami była wieża z kości słoniowej. Znajdowały się na niej: kaduceusz Merkurego (Panna roztropna), różaniec (Panna czcigodna), książeczka Ewangelii (Panna wsławiona), buława (Panna można), berło (Panna łaskawa), pierścień na wieńcu z kwiatów (Panna wierna), tron (Stolica mądrości), trąba z rulonem, na którym umieszczone były nuty (trąba - Przyczyna naszej radości; karta z nutami - Kyrie eleison, Christe eleison). Poniżej wieży z kości słoniowej umieszczony był konfesjonał (Ucieczka grzeszników). Z wieżami były związane jeszcze dwa symbole - domek (Dom złoty) oraz arka z głową serafina (Arka Przymierza). Nie jest jasne, do której wieży należy je przypisać. Ponieważ jednak domek wyrzeźbiony był poniżej wieży, a miejsce poniżej wieży z kości słoniowej zajmował konfesjonał, to domek prawdopodobnie umieszczony był po drugiej stronie pod wieżą Dawidową. Na tej wieży, dla zachowania zbliżonej liczby symboli na obu wieżach, powinna znaleźć się także arka. Strukturę ołtarza uzupełniało rozbudowane zwieńczenie. Składało się nań wyobrażenie Trójcy Świętej (Boga Ojca, Chrystusa i Ducha Świętego), anioła trzymającego koronę (Królowo Aniołów) i umieszczone na szczycie przedstawienie Baranka na księdze z siedmioma pieczęciami, odpowiadające zakończeniu litanii. Obok anioła znajdowała się także korona z insygniami, odnosząca się do wezwania „Królowo Patriarchów". Kolejne wezwania, określające Marię jako królową, także były zobrazowane przez korony. W opisie dokładnie określono miejsca dwóch z nich: w szczycie ołtarza była umieszczona korona cesarska zestawiona z uszami, które obrazowały wezwanie „Chryste usłysz nas, Chryste wysłuchaj nas”, a koronę odnoszącą się do wezwania „Królowo Wszystkich Świętych” trzymali Bóg Ojciec i Chrystus. Miejsca pozostałych koron opis nie określa. Ponieważ jednak najczęściej poszczególne symbole wymieniane są w nim w kolejności umieszczenia, a kolejne korony pojawiają się po tych powiązanych z przedstawieniem anioła, można przypuszczać, że także one usytuowane były koło lub wokół niego. Najprawdopodobniej więc tam także znajdowała się korona z lunetą przedstawiająca „Królową Proroków”, korona z gałązką palmową jako wyobrażenie „Królowej Męczenników”, wianek przywołujący wezwanie „Królowa Dziewic” oraz umieszczone na poduszkach - tiara papieska (Królowa 
Apostołów) i korona z mieczem (Królowa Męczenników). Ostatnią z wymienionych w opisie koron trzymał w dziobie polski orzeł. Opis wyraźnie wskazuje, że niektóre korony były powiązane z innymi symbolami oraz że miały różne formy ${ }^{62}$. Elementem uzupełniającym kompozycję nastawy było zwierciadło umieszczone poniżej wyzłoconego imienia Marii, odpowiadającego wezwaniu „Święta Maryjo”. Opis dotyczący tych elementów nie określa dokładnie miejsca ich usytuowania ani nie precyzuje jaką miały formę. O ile w przypadku imienia Marii można przyjąć, że reprezentował je monogram ${ }^{63}$, to określenie jaką formę miało lustro nie jest już możliwe. Mogło być bowiem zarówno namalowanym lub wyrzeźbionym przedmiotem, jak i prawdziwym lustrem wmontowanym w retabulum lub w pole wyrzeźbionego zwierciadła. Z boku zwierciadła dodana była lilia oznaczająca "Świętą Pannę nad pannami”, a po lewej stronie znajdowała się róża (Róża duchowna) oraz oko z promieniem (Matka łaski Bożej). Skoro obok nich zgrupowano inne symbole możemy przypuszczać, że zarówno imię Marii, jak i lustro były większymi elementami kompozycji. Najprawdopodobniej były umieszczone pomiędzy wizerunkiem Marii z Dzieciątkiem a przedstawieniem Boga Ojca i Chrystusa. W takim układzie trzymana przez nich korona wieńczyłaby monogram - „imię Marii”.

Nie wykluczone, że nie tylko opisem, ale i rozmieszczeniem poszczególnych symboli w nastawie rządził układ wezwań Litanii. W takiej sytuacji nastawę można być może uznać za wizualizację Litanii, która mogła być wykorzystana (zgodnie $\mathrm{z}$ technikami mnemonicznymi) podczas odmawiania modlitwy. Analizując usytuowanie symboli w nastawie możemy zauważyć, że część z nich była zgrupowana w zestawy obejmujące przedstawienia zbliżonego rodzaju. Nad wizerunkiem Marii umieszczone były naczynia, kwiaty obok zwierciadła, a korony najprawdopodobniej wokół anioła. Połączenia symboli mogłyby rozbudowywać program nastawy o dodatkowe treści. Obok symboli ukazujących naczynia umieszczona była gałązka winnego grona, która razem z nimi mogłaby się odnosić do ofiary mszy świętej. Niektóre zestawienia, jak na przykład lustro i gwiazda, pojawiają się w ikonach emblemów ${ }^{64}$. Jednak autor Kroniki nie wspomina o takiej możliwości odczytywania symboli.

Najciekawszymi elementami ołtarza były umieszczone po bokach wieże. Pewne wyobrażenie o tym jak mogły wyglądać mogą stanowić dzieła, w których

\footnotetext{
62 Takie zróżnicowanie form koron pojawia się w przedstawieniach odwołujących się do Litanii Loretańskiej. Za przykład może posłużyć obraz w antepedium ołtarza głównego w kaplicy pielgrzymkowej Wniebowzięcia NMP w Birkenstein (Górna Bawaria), namalowany przez Sebastiana Trogera około 1765 roku. Zob.: http://iconographic.warburg.sas.ac.uk/vpc/VPC_search/pdf_frame. php?image $=00062823$ [10.11.2017].

63 Monogram Marii połączony z tym wezwaniem pojawia się na przykład w Lauretanische Litaney (DORN 1749, [b. s.]).

64 Np.: BRUCK 1615, k. 19.
} 




pojawiają się dodatkowe przedstawienia czy symbole umieszczone na elementach, które - podobnie jak wieże - można interpretować symbolicznie. Antyczne kolumny Trajana i Marka Aureliusza oraz zachowane w Rzymie oryginalne egipskie obeliski z hieroglifami, odczytywanymi niekiedy w okresie nowożytnym jako tajemne znaki - symbole ${ }^{65}$, mogły stanowić tu dobre wzorce i były też wielokrotnie wykorzystywane. Obeliski, kolumny, filary z zawieszonymi symbolami bądź dodatkowymi 
Lubawa, kościół św. Barbary,

ołtarz główny,

Ephraim Gerlach, 1769-1773,

fot. Renata Sulewska

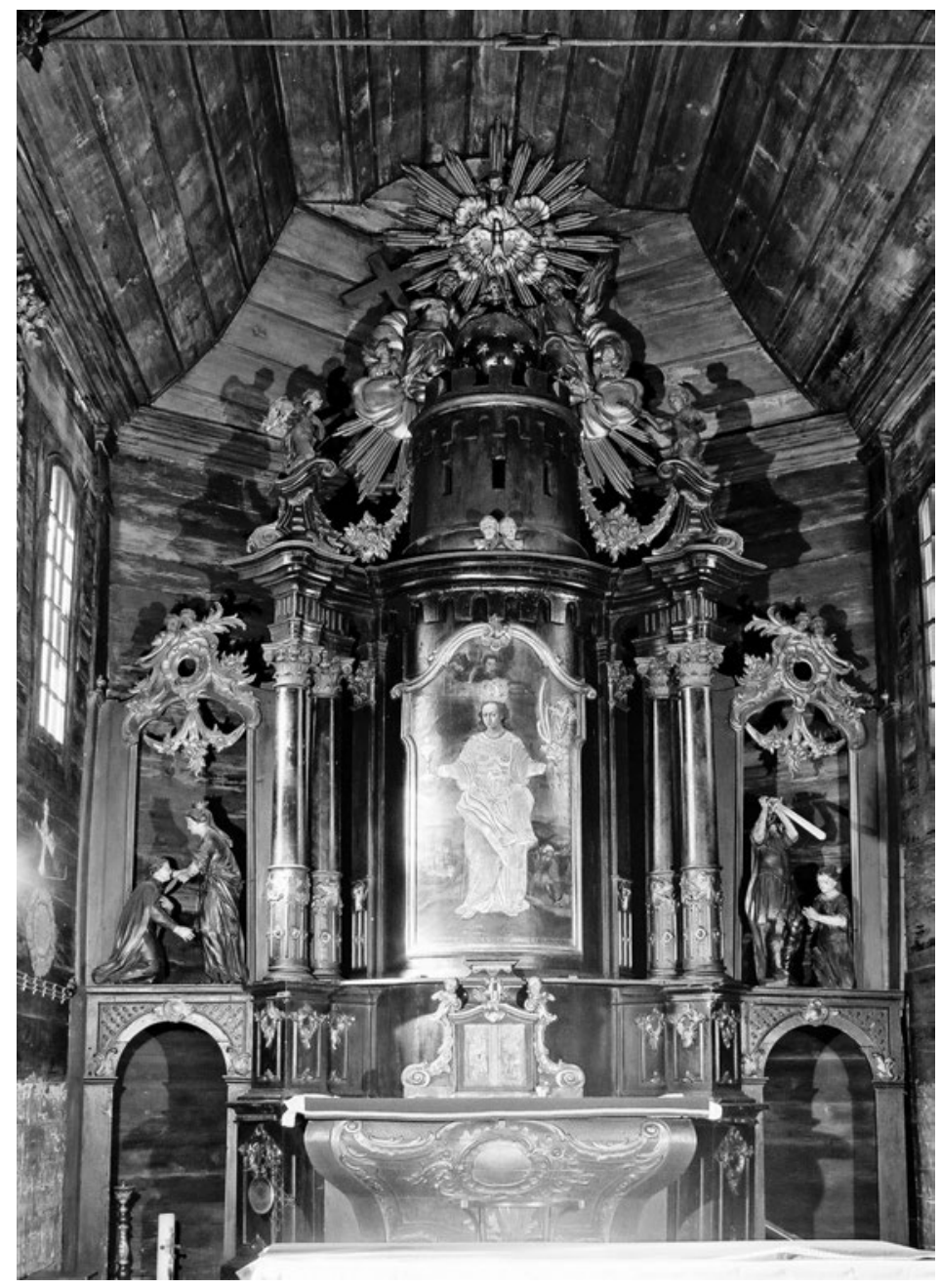

przedstawieniami w kartuszach pojawiały się dość często w różnego typu dziełach ${ }^{66}$, także małej architektury. Szczególnie popularne były w dekoracjach okazjonalnych, również tych religijnych. Jako przykłady mogą tu posłużyć chociażby: dekoracja na

66 Interesujące w kontekście ołtarza poznańskiego mogą być na przykład: ilustracja z dwiema kolumnami, na których zostały ukazane symboliczne przedstawienia cnót władcy, umieszczona po stronie tytułowej, w: WEBER 1662 (zob.: KNAPP/TÜSKÉS 2003, il. 18) oraz seria rycin Josepha Sebastiana i Johanna Bapristy Klauberów według inwencji Gottfrieda Bernharda Göza z wizerunkami Chrystusa, Marii i dwunastu apostołów, w której popiersiowe przedstawienia Chrystusa, Marii i św. Piotra zostały ujęte przez obeliski. Na obeliskach towarzyszących Chrystusowi zostały zawieszone atrybuty apostołów. Wizerunek Marii został zestawiony z ujętymi w kartusze scenami męczeństwa apostołów, natomiast św. Piotra z symbolami odnoszącymi się do jego posługi i pochodzenia. Zob.: PESSCA 1975A, https://colonialart.org/galleries/gallery-11-the-remarkable-apostles-of-gozklauber-rodriguez\#c1975a-1975b, [11.11.2017]. 
nabożeństwo czterdziestogodzinne do jednego z rzymskich kościołów, być może SS. Vincenzo e Anastasio, zaprojektowana przez Giovanniego Battistę Gisleniego (który wzdłuż bocznych ścian świątyni ustawił obeliski z hieroglifami natomiast na jej belkowaniu piramidy ${ }^{67}$ ) oraz dekoracja wnętrza kościoła w Lądzie, przygotowana na jubileuszowe obchody sześćsetlecia fundacji cysterskiego opactwa, której najważniejszym elementem był baldachim wsparty na sześciu kolumnach, na których były zawieszone emblemy, portrety i herby ${ }^{68}$.

O możliwości wprowadzenia do kompozycji nastawy zmonumentalizowanego elementu symbolicznego mogą świadczyć dzieła określone niegdyś przez Jana Samka jako res-imagines ${ }^{69}$. W kontekście retabulum poznańskiego należy przywołać oba wspomniane już ołtarze z dodanymi po bokach obeliskami w kościele w Dzierzgoniu oraz wykonany przez Ephraima Gerlacha w latach 1769-1773 ołtarz główny w kościele św. Barbary w Lubawie ${ }^{70}$, którego cała środkowa część ma formę wieży - atrybutu patronki świątyni.

Skomplikowaniem rozwiązań narzuconych przez treść, ale i zapewne formą poznański ołtarz NMP różnił się od nastaw powstających od połowy XVIII wieku dla kościołów reformatów prowincji wielkopolskiej ${ }^{71}$. Przeznaczony do klasztoru, nie kościoła, nie musiał zapewne powielać ustalonych wzorców. Józef Hybner, realizujący zamówienie na ołtarz główny poznańskiej świątyni zapewne zgodnie z zaleceniem zamawiających, sięgnął do modelowego rozwiązania, jakim dla reformackich kościołów tej prowincji stał się wystrój kościoła Reformatów w Boćkach ${ }^{72}$. Autor Kroniki ocenił jego pracę jako wykonaną ,wedle kanonów dawnej sztuki, bardzo różniących się od współczesnych”73. Natomiast o ołtarzu NMP napisał, że był „zręcznie wykonany"74. 


\section{Aneks:}

Archiwum Archidiecezjalne w Poznaniu, AZ 009/009, Scrutinium antiquitatis sive nova revisio veteris archiviiconventus ad S. Casimirum Patr. R. Pol. Posnan[i]e[nsis] PP. S. Francisci Reformatorum in II Libros Divisa. Ab Anno ejus Fundationis 1657, s. $52-53$.

[na marginesie: 90. Litaniae Lauretanae Altare BV Mariae]

Pro Memoria, et Conservatione praefatiAltaris

Explicantur singula in eodem contenta Litaniarum mysteria

Kyrie eleison, Chryste eleison patet in convoluta papyro musica vulgo Partytura dicta Tubae cornutae apposita in Turri eburnea a latere dextro Altaris.

Christe audi nos.Christe exaudi nos: designat aures in vertice Altaris ad latera Coronae Caesareae fixae.

Pater de coelis Deus, Filius Redemptor, Spiritus S. et S. Trinitas unus Deus prominent in vertice Altaris patenter.

Sancta Maria apparet super speculum in Nomine Mariae deaurato. 
Sanctam Dei Genitricem

Sanctam Virginem Virginum

Matrem Jesu Christi

Matrem Divinae Gratiae

Matrem Purissimam

Matrem Castissimam

Matrem Inviolatam

Matrem Intemeratam

Matrem Amabilem

Matrem Admirabilem

Matrem Creatoris

Matrem Salvatoris

Virginem Prudentissimam

Virginem Venerandam

Virginem Praedicandam

Virginem Potentem

Virginem Clementem

Virginem Fidelem

Speculum Iustitiae

Sedem Sapientiae

Causa mnostrae laetitiae

Vas Spirituale

Vas Honorabile

Vas insigne Devotionis

Rosam Mysticam

Turrim Davidicam

Turrim Eburneam

Domum Auream

Foederis Arcam

Ianuam Coeli

Stellam Matutinam

Salutem Infirmorum

Refugium Peccatorum

Consolatricem Afflictorum

Auxilium [Chri]stianorum

Reginam Angelorum

Reginam Patriarcharum

Reginam Prophetarum

Reginam Apostolorum

Reginam Martyrum

Reginam Confessorum

Reginam Virginum

Reginam SS. Omnium

Reginam Regni Poloniae
Stella 3. Magoru[m] Infantem praesentans.

Lilium inter flores ad latus speculi fixum.

Ipsa Imago in Altari Christum gestans.

Oculus cum radio a latere sinistro speculi.

Cristallu[m] Turri Davidicae superfixum.

Sol in eadem Turri, qui lutum tangit nec maculatur.

Epistola obsigillata eidem Turria ffixa.

Sigillum affixum q[uo]d temere non assumit[ur].

Cor in eadem Turri sculptum.

Instrumentum Arcularii cum Campana.

Mundus ad latus turris prominens.

5 Vulnera[Chri]sti in eadem Turri sculpta.

Caduceus Mercurii in Turri eburnea a dextris.

Rosarium in eadem Turri eburnea.

Libellus Evangeliorum eidem turri affixu[s].

Clava Belli Ducum in eademTurri.

Sceptrum Signum Clementiae ibidem.

Annulus ibidem in fronde florum.

Speculum subtus Nomen Mariae.

Curulis in eadem Turri sculpta.

Tuba cornuta cum scripturis musicis.

Calix cum patena super Iconem.

Pyxis S[anctis] simi ibidem a dextris.

Thuribulum a sinistris Altaris pendens.

Rosa a sinistris speculi.

Turris a sinistris Altaris.

Turris a dextris eiusdem.

Domuncula subt[us] turrim sculpta.

Arca eadem cum seraphini capite in turri.

Medium Altaris Iconem ambiens.

Stella super Iconem.

Pyxis Pharmacopolea super Iconem.

Confesionale subtus Turrim eburneam.

Botrus vini de vite super Iconem.

Scutum cum gladio a sinistris Iconis.

Angelus coronam gestans in vertice Alt[aris].

Corona cum insigniis eorum prope Angel[um].

Corona cum perspectiva.

Triregium Papale in cussino.

Corona cum Gladio in culcitra a dextris.

Corona cum Palma designat.

SertumViriginale.

Corona a Deo Patre et Filio manutenta.

Aquila Polona Coronam rostro tenens.

Agnus Dei qui tollit peccata mundi, patet in ipsa summitate Altaris, super Librum signatum

7. Sigillis, 7. Peccata Capitalia denotantibus. Christe audi nos. etc. Kyrie eleison etc. ut supra. 


\section{Bibliografia:}

\section{Źródła rękopiśmienne:}

- AAPoz, AZ 009/009 - Archiwum Archidiecezjalne w Poznaniu, AZ 009/009, Scrutinium antiquitatis sive nova revisio veteris archivii conventus ad S. Casimirum Patr. R. Pol. Posnan[i]e[nsis] PP. S. Francisci Reformatorum in II Libros Divisa. Ab Anno ejus Fundationis 1657.

\section{Źródła drukowane:}

- BRUCK 1615 - Jacobus à Bruck, Angermundt Cogn. Sil. Emblemata moralia \& bellica. Nunc recens in luceme dita, Argentorati 1615.

- DORN 1749 - Franz Xaver Dorn, Lauretanische Litaney, So Zu Lob, und Ehr Der Ohne Mackel empfangenen, Von aller Sündbefreyten, Unbefleckten Jungfrauen, und Glorwürdigisten Himmels-Königin Mariae: Das Erstemahl In demWunder-thätigen Hauß Loreto von denen Heiligen Englen ist abgesungen Nachmahls Von der Catholischen Kirchen angenommen, Und von Clemente VIII. Römischen Pabsten bestätiget worden; Nunmehro aber Fast aus allen Chören mit Freuden vollen Jubel angestimmet / und von wahren Dienern, und Marianischen Liebhabern nicht ohne grösten Trost vil Tausend mahl gebetten wird: durch Klare Concept, fassbare Sinn-Bilder, Gleichnussen, und Biblische Figuren, in siben und fünfzig Kupffer-Stichen nach Ordnung der Ehren-Titlen fürgestellt, und mit kurtzer Beyschriften erklärt von Franciscus Xaverius Dornn, Dechant und Ordinari-Predigern in Fridberg, Augspurg 1749, https://books.google.pl/books?id=HpRhAAAAcAAJ\&p$\mathrm{g}=\mathrm{PT} 4 \& \mathrm{lpg}=\mathrm{PT} 4 \& \mathrm{dq}=\mathrm{dornn}+$ lauretanische $\&$ source $=\mathrm{bl} \& \mathrm{ots}=\mathrm{iCd} 61 \mathrm{v} 27 \mathrm{ad} \& \mathrm{sig}=\mathrm{yImwH} 64 \mathrm{k} 6 \mathrm{AlXG}$ 75vBMXbJvjrV1w\&hl=pl\&sa=X\&ved=0ahUKEwjP8Oj14KjXAhUJJuwKHddND_kQ6AEINDAC\#v=onepage\&q=dornn\%20lauretanische\&f=false [05.11.2017].

- JARMUNDOWICZ 1746 - Kazimierz Jarmundowicz, Fundacya kościoła i klasztoru lendzkiego Świętego Zakonu Cystercyeńskiego sześciu wiekami trwałości swojej stwierdzona, Poznań 1746.

- MARIOPHILO 1680 - Theophilo Mariophilo (Abraham a Sancta Clara), Stella ex Jacob Orta, MARIA, cujus Sacrae Litaniae Lauretanae tot Symbolis, quot Tituli, Tot Elogijs, qupt literae in quovis Título numerantur, Viena 1680, http://books.google.es/books?id=gTZOAAAAcAAJ\&printsec=frontcover\&hl=es [02.05.2017].

- MARRACCI 1683 - Hippolit Marracci, Polyanthea mariana in libros XVIII distribute in qua deiparae Virginis Mariae Nomina \& selectoria Encomia ex SS. Patrum aliorumq; sacrorum Scriptorum, praesertim veterum, monumentis collecta, juxta alphabeti seriem, \& temporis, quo iidem vixerunt, ordinem disposita, Lectorum oculis exhibentur, Köln 1683, https://books.google.pl/books?id=RchBAAAAcAAJ\&printsec=frontcover\&hl=pl\&source=gbs_ge_summary_r\&cad $=0 \# \mathrm{v}=$ onepage $\& \mathrm{q} \& \mathrm{f}=$ false [05.11.2017].

- OXOVIENSIS 1700 - Isaac Oxoviensis, Elogia Mariana Ex Lytaniis Lauretanis Deprompta, Ac Sacro Poemate Rythmico, Biblicis Sententiis, ac Figuris, solidis sanctorum Patrum effatis, ac variis probatorum Auctorum Discursibus. Quae omnia In Annotationibus post quaelibet Poemata apponuntur ad longum, luculenter explanata. Opus non solum fovendae devotioni erga Beatissimam Virginem per opportunum, sed etiam Panegyricis de Eadem sermonibus efformandis accommodatissimum/ Auctore P.F. Isaaco Oxoviensi, Capucino Concionatore, Cum variis figuris aereis, iam olim ingeniose inventis, nunc denuo cum additionen ovorum Versuum excusis, $\&$ ad singula Elogia concinne accommodates, Augustae 1700, http://diglib.hab.de/drucke/xb-2952/start.htm [05.11.2017].

- REDEL 1732 - August Casimir Redel, Elogia Mariana Olim A. C. Redelio Belg: Mechl: S.C.M.L.P concepta Nunc devotae Meditationi fidelium ad augmentum cultus Bmae Mariae Virg: Deiparae inventa et delineata per Thomam Scheffler et aeri incisa à Martino Engelbrecht Chalcographo Augustano Cum Priv. Sac. Caes. Maj, Augsburg 1732, https://archive.org/details/elogiamarianaoli00enge [05.11.2017].

- STOERGLER 1636 - Peter Stoergler, Asma Poeticum Litaniaru[m] Lauretanarum: [in quo singulis titulis emblemata cum carmine respondent], Linz 1636, https://archive.org/details/asmapoeticumlita00stoe [05.11.2017]. 
- WEBER 1662 - Johannes Weber, Janus bifrons seu Speculum Physico-Politicum. Das ist Naturlicher Regenten Spiegel..., Leutschoviae 1662.

- ZOLLER 1720 - Joseph Zoller, Conceptus chronographicus de concepta sacra deipara: Septingentis sacrae scripturae, SS. Patrum, ac rationum, nec non historiarum, symbolorum, antiquitatum, et anagrammatum suffragiis roboratus, ac totidem praefixis chronographicis, annum currentem prodentibus copiose instructus, Augustae 1720, https://books.google.pl/books/about/Conceptus_chronographicus_de_concepta_sa.html?id=YBIOAAAAQAAJ\&redir_esc=y [05.11.2017].

\section{Opracowania:}

- AMARAL 2011 - Rubem Amaral Jr., Bibliography of the Litany of Loretto Illustrated with Emblematic Plates by the Brothers Klauber, of Augsburg, or after Them, „The Society for Emblem Studies Newsletter”, (2011), nr 48, January, s. 10-16, http://german.lss.wisc.edu/ smoedersheim/ses/SESNewsletter48.pdf [05.11.2017].

- AMARAL 2014 a - Rubem Amaral Jr., Addendum to the Bibliography of the Litany of Loretto (Rubem Amaral Jr.: "Bibliography of the Litany of Loretto illustrated with emblematic plates by the Brothers Klauber, of Augsburg, or after them”), „Society for Emblem Studies Newsletter”, (2014), nr 54, January, s. 18, http://german. lss.wisc.edu/ smoedersheim/ses/SESNewsletter54.pdf [09.11.2017]

- AMARAL 2014 b - Rubem Amaral Jr: Addenda et Corrigenda to the Bibliography of the Litany of Loretto ("Bibliography of the Litany of Loretto illustrated with emblematic plates by the Brothers Klauber, of Augsburg, or after them”), „Society for Emblem Studies Newsletter”, (2014), nr 55, July, s. 17-18, http://doczz.net/ doc/5841254/ses-newsletter---the-society-for-emblem-studies [09.11.2017].

- BARKER 2010 - Margaret Barker, The Images of Mary in the Litany of Loreto, „Usus Antiquior”, t. 1 (2010), nr 2, s. 110-131, http://www.margaretbarker.com/Papers/USU_Barker.pdf [05.11.2017].

- BIERNACKA 1987 - Małgorzata Biernacka, Niepokalane Poczęcie, [w:] Małgorzata Biernacka, Tomasz Dziubecki, Hanna Graczyk, Janusz St. Pasierb, Maryja matka Chrystusa, Warszawa 1987, s. 27-93.

- BŁACHUT 1975 - Adam Błachut, Eglauer (Eglaur) Józef, [w:] Słownik artystów polskich i obcych w Polsce działajacych, malarze, rzeźbiarze, graficy, t. 2, Wrocław-Warszawa-Kraków-Gdańsk 1975, s. 157.

- BŁACHUT 2003 - Adam Jan Błachut, Brat Mateusz Osiecki i jego dzieło. Modelowy projekt nowego wystroju wyposażenia kościołów reformackich prowincji wielkopolskiej w XVIII wieku, Warszawa2003.

- BŁACHUT 2006 - Adam Jan Błachut, Słownik artystów reformackich w Polsce, Warszawa 2006.

- DOMASŁOWSKI 1981 - Jerzy Domasłowski, Kościół i klasztor w Lądzie, Poznań-Warszawa 1981.

- FERNÁNDEZ GRACIA 2004 - Ricardo Fernández Gracia, Algunas representaciones inmaculistas hispanas del siglo XVIII. Fuentes gráficas y literarias y los defensores del misterio concepcionista, „Anuario de Historia de la Iglesia”, t. 13 (2004), s. 45-65.

- FOURNÉE 1970 - Jean Fournée, Immaculata conceptio (Unbefleckte Empfängnis Mariens), [w:] Lexikon de christlichen Ikonographie, Bd. 2, Hrsg. Engelbert Kirschbaum, Rom-Freiburg-Basel-Wien 1970, kol. 338-344.

- GLEMMA 1956 - Tadeusz Glemma, Śluby Jana Kazimierza, „Ruch Biblijny i Liturgiczny”, t. 9 (1956), nr 4-6, s. 187-203.

- GROËR 1995 - Hans Hermann Groër, Litania Loretańska, tłum. Georg Knapik, Stanisław Pisarek, Katowice 1995.

- GRZYBEK 1951 - Stanisław Grzybek, Powstanie i rozwój Litanii do Najśw. Marii Panny, „Ruch Biblijny i Liturgiczny", t. 4 (1951), nr 1, s. 97-108.

- KAŁAMAJSKA-SAEED 1980 - Maria Kałamajska-Saeed, Modelowy wystrój kościoła Reformatów w Boćkach, „Biuletyn Historii Sztuki”, t. 42 (1980), nr 2, s. 145-158.

- KZSP 5, 11 - Katalog zabytków sztuki w Polsce, t. 5: Województwo poznańskie, red. Teresa Ruszczyńska, Aniela Sławska, z. 11: Powiat krotoszyński, inwentaryzację przeprowadzili Zofia i Janusz Kębłowscy, Warszawa 1973.

- KZSP 11, 4 - Katalog zabytków sztuki w Polsce, t. 11: Województwo bydgoskie, red. Tadeusz Chrzanowski, Marian Kornecki, z. 4: Dawny powiat chetmiński, oprac. Teresa Mroczko, Warszawa 1976. 
- KZSP, Sn, 7, 1 - Katalog zabytków sztuki w Polsce, Seria nowa, t. 7: Miasto Poznań, red. Eugeniusz Linette, Zofia Kurzawa, cz. 1: Ostrów Tumski i Śródka z Komandoriq, Warszawa 1983.

- KEMP 1989 - Cornelia Kemp, Emblem, [w:] Marienlexikon, Bd. 2, Hrsg. Remigius Bäumer, Leo Scheffczyk, Sankt Ottilien 1989, s. 331-334.

- KLAWEK 1956 - Aleksy Klawek, Biblijne symbole maryjne, „Ruch Biblijny i Liturgiczny”, t. 9 (1956), nr 4-6, s. 216-227.

- KNAPP/TÜSKÉS 2003 - Éva Knapp, Gábor Tüskés, Emblematics in Hungary. A Study of the History of Symbolic Representation in Renaissance and Baroque Literatur, Tübingen 2003.

- KNAPIŃSKI 1999 - Ryszard Knapiński, Titulus ecclesiae. Ikonografia wezwań współczesnych kościołów katedralnych $w$ Polsce, Warszawa 1999.

- KNAPIŃSKI 2005 - Ryszard Knapiński, Potrydencka ikonografia maryjna w sztuce europejskiej i polskiej, „Studia Claromontana”, t. 23 (2005), s. 29-54.

- Kronika Reformatów poznańskich 2006 - Kronika Reformatów poznańskich, oprac. Jacek Wiesiołowski, Salezy Bogumiła Tomczak, Grzegorz Antoni Wiśniowski, Poznań 2006.

- KURZAWA 1997 - Zofia Kurzawa, Zapomniany klasztor. Dawny kościót i klasztor oo. Reformatów, „Kronika Miasta Poznania", 1997, nr 1: Śródka, Ostrówek, Św. Roch, s. 129-152.

- LÓPEZ CALDERÓN 2010-2012 - Carme López Calderón, Magna Dei Parens ac Virgo Maria est: La apología mariana a través de la emblemática en una letanía seiscentista, „Revista da Faculdade de Letras, Ciências e Técnicas do Património", t. 9-11 (2010-2012), s. 82-107.

- LÓPEZ CALDERÓN 2012-2013 - Carme López Calderón, El dulce nombre de María: etimología, anatomía, efectos y plástica de los siglos XVII-XVIII, „Norba: Revista de Arte”, (2012-2013), nr 32-33, s. 63-84.

- LÓPEZ CALDERÓN 2013 - Carme López Calderón, Quién es quién en la Elogia Mariana de A. C. Redelio, [w:] Barroco Iberoamericano. Identidades culturales de un Imperio, vol. 1, coords. Carme López Calderón, María de los Ángeles Fernández Valle, María Inmaculada Rodríguez Moya, Santiago de Compostela 2013, s. 51-63.

- LÓPEZ CALDERÓN 2016 - Carme López Calderón, Letanías emblemáticas: símbolos marianos de maternidad, virginidad y mediación en la Edad Moderna, [w:] Regina Mater Misericordiae. Estudios históricos, artísticos y antropológicos de advocaciones marianas, coords. Juan Aranda Doncel, Ramón de la Campa Carmona, Córdoba 2016, s. 413-430.

- LÜDICKE-KAUTE 1971 - Lore Lüdicke-Kaute, Lauretanische Litanei, [w:] Lexikon de christlichen Ikonographie, Bd. 3, Hrsg. Engelbert Kirschbaum, Rom-Freiburg-Basel-Wien 1971, kol. 27-31.

- ŁUKARSKA 2010 - Beata Łukarska, Symbolika maryjna w wybranych tekstach polskiego średniowiecza i baro$k u$, „Świat i Słowo”, Filologia. Nauki Społeczne. Filozofia. Teologia, (2010), nr 2 (15), s. 171-183.

- ŁYCZAK 2015 - Bartłomiej Łyczak, Uwagi na temat nastaw oltarzowych ufundowanych w XVIII wieku do kościoła pw. śś. Jana Chrzciciela i Jana Ewangelisty w Toruniu, „Zapiski Historyczne”, t. 80 (2015), z. 2, s. 77-91, http://dx.doi.org/10.15762/ZH.2015.20 [02.11.2017].

- MICHALCZYK 2016 - W lustrzanym odbiciu. Grafika europejska a malarstwo Rzeczypospolitej w czasach nowożytnych ze szczególnym uwzględnieniem późnego baroku, Warszawa 2016.

- MONTERROSO MONTERO 2003 - Juan Manuel Monterroso Montero, Mitología y emblemática en la iconografía mariana, [w:] Barroco: Actas do II Congresso Internacional, coord. Sanches Fausto Martins, Porto 2003, s. 365-378, http://ler.letras.up.pt/site/default.aspx?qry=id03id1291\&sum=simhttp://ler.letras.up.pt/uploads/ ficheiros/7547.pdf [05.11.2017].

- MONTERROSO MONTERO 2004 - Juan Manuel Monterroso Montero, Emblemática e iconografía mariana. Imágenes emblemáticas de la Litaniae Lauretanae de Francisco Xavier Dornn, [w:] Florilegio de estudios de Emblemática $=$ A Florilegium of Studies on Emblematics: Actas del VI Congreso Internacional de Emblemática de The Society for Emblem Studies = Proceedings of the 6th International Conference of The Society for Emblem Studies, red. Sagrario López Poza, Ferrol 2004, s. 541-552. 
- MOSSAKOWSKI 2002 - Stanisław Mossakowski, Projekt „Teatro di Quarantore” dla kościoła w Rzymie, [w:] idem, Orbis Polonus. Studia z historii sztuki XVII-XVIII wieku, Warszawa 2002, s. 164-196.

- NOWIŃSKI 2008 - Janusz Nowiński, Nagrobek opata-mecenasa Mikołaja Antoniego Eukomskiego w pocysterskim kościele w Lądzie nad Warta, „Biuletyn Historii Sztuki”, t. 70 (2008), nr 3-4, s. 385-406.

- SAMEK 1970 - Jan Samek, Res-imagines. Ze studiów nad rzemiosłem artystycznym czasów nowożytnych $w$ Polsce (lata 1600-1800), „Rocznik Historii Sztuki”, t. 8 (1970), s. 177-248.

- SKRUDLIK 1930 - Mieczysław Skrudlik, Królowa Korony Polskiej. Szkice z historii malarstwa i kultu Bogarodzicy w Polsce, Lwów 1930.

- SOKOLSKI 2000 - Jacek Sokolski, Słownik barokowej symboliki natury, tom wstępny: Barokowa księga natury, Wrocław 2000.

- STOLL 2013 - Peter Stoll, Zweites Augsburger Rokoko. Die Lauretanische Litanei der Brüder Klauber und ihre Rezeption in Frankreich, Augsburg 2013, http://opus.bibliothek.uni-augsburg.de/opus4/frontdoor/index/index/year/2013/docId/2362 [ 05.11.2017].

- STOLL 2014 - Peter Stoll, Augsburger Rokoko, purifiziert. Eine Holzstichadaption der Lauretanischen Litanei der Brüder Klauber, Augsburg 2014, https://opus.bibliothek.uni-augsburg.de/opus4/frontdoor/index/index/ year/2014/docId/2716 [05.11.2017].

- STOLL 2016 - Peter Stoll, Regina martyrum - Ein Fresko von Franz Nikolaus Streicher in Höglwörth nach der Lauretanischen Litanei der Brüder Klauber, s. 1-20, Augsburg 2016, https://opus.bibliothek.uni-augsburg.de/ opus4/frontdoor/index/index/docId/3697 [05.11.2017].

- SZCZEPIŃSKA 2016 - Kinga Szczepińska, Historia, stan aktualny i potrzeby konserwatorskie wyposażenia kościoła pw. Trójcy Przenajświętszej w Dzierzgoniu. Rozważania na kanwie prac przeprowadzonych $w$ latach 2008-2015, „Acta Universitatis Nicolai Copernici”, Zabytkoznawstwo i Konserwatorstwo, t. 47 (2016), s. 169199.

- WARDZYŃSCY 2013 - Katarzyna i Michał Wardzyńscy, Nieznane nastawy w kościołach Reformatów w Choczu i Dzierzgoniu z 1. ćw. XVIII w., [w:] Non cesso gratis agere Deo et hominibus. Prace ofiarowane Ojcu dr. Anzelmowi Januszowi Szteinke OFM z okazji Złotego Jubileuszu Kapłaństwa i ponad 50-lecia pracy historyczno-pisarskiej, red. Wacław Marian Michalczyk, Celestyn Mieczysław Paczkowski, Kraków - Warszawa 2013, s. 859-884.

- WARDZYŃSKA 2012 - Katarzyna Wardzyńska, Ephraim Gerlach rzeźbiarz chetmiński doby późnego baroku i rokoka, [w:] Splendor i fantazja. Studia nad rzeźba rokokowa w dawnej Rzeczypospolitej i na Ślasku, red. Paweł Migasiewicz, Warszawa 2012, s. 139-194.

- WARDZYŃSKA 2014 - Katarzyna Wardzyńska, Johannes Soffrens (1660 - po 1721) - rzeźbiarz niderlandzki w Elblagu. Wstęp do monografii, „Porta Aurea”, 13 (2014), s. 136-159.

- WOJTCZAK 2010 - Adam Wojtczak, W sprawie tytułów maryjnych i ich rozumienia, „Perspectiva: Legnickie Studia Teologiczno-Historyczne", t. 9 (2010), nr 2(17), s. 257-289.

- WOJTCZAK 2011 - Adam Wojtczak, Pochodzenie i rozwój maryjnego tytułu „Gwiazda Zaranna”, „Studia Koszalińsko-Kołobrzeskie”, t. 17 (2011), s. 161-185.

- ZINKOW 2009 - Leszek Zinkow, Imhotep i pawie pióra. Z dziejów inspiracji egipskich w architekturze polskiej, Kraków 2009. 


\section{Representation of the Litany of Loreto in the Altarpiece of the BVM in the Franciscans of Primitive Observance Monastery
in Poznań}

ciscans of Primitive Observance in Poznań, one more retable was made in 1763 , this time for the monastery. It was placed in the 'lower cloister', next to the entrance to the refectory. The retabulum intended for the monastery has not survived and is known only from a description included in The Chronicle of the Franciscans of Primitive Observance in Poznań (Kronica Reformatow poznańskich). The altarpiece was dedicated to the Blessed Virgin Mary, and its imagery encompassed the symbols that presented invocations from the Litany of Loreto, commencing with the Kyrie eleison, to the Lamb of God. Presumably, the set of symbols in the Poznan 
retable, which corresponded to individual invocations, was not based on a single source. Even if it were possible to determine one such source, however, the altarpiece was significantly modified by the introduction of symbols of a 'local' origin, such as the representation of the Polish eagle with a crown in his beak, referring to the invocation Regina Regni Poloniae, or the image of a woodworking plane and a bell that symbolized invocation Mother most admirable. This last image referred back to events that had taken place in the Poznań monastery and could not have been correctly interpreted without information contained in The Chronicle. Symbols and emblems recorded in the text offer a point of departure for reconstructing the Poznań retabulum. In general, these retables can be divided into two major types. The first one has an architectonic organization enriched with sculpted symbols or cartouches with relief designs applied to the frame or supported by sculpted figures placed in the structure. The second type is represented by non-architectonic retables where imagery is incorporated into an ornamental frame. As can be inferred from the description in The Chronicle, the altar dedicated to the BVM within the Franciscan monastery belonged to the former type. This description also makes it possible to reconstruct the retable - an aedicula with towering structures on both sides and an elaborate crowning section. All its elements - the structure and the complementing representations - had a symbolic meaning. Given the complexity of applied solutions (imposed by its content and symbolism) and its elaborate form, the Poznań altar dedicated to the BVM differed from other retables that were constructed in Franciscan churches in the territories of Greater Poland in the second half of the 18th century, most of them modelled on the retables in the Franciscan church in Boćki. 